\title{
Chemical characterization and pharmacological action of Brazilian red propolis
}

\author{
Marcela Lins Cavalcanti de Pontesa*, Inácio Ricardo Alves Vasconcelos ${ }^{\mathrm{b}}$, Margareth de Fátima \\ Formiga de Melo Diniza ${ }^{a}$ Hilzeth de Luna Freire Pessôab \\ a Programa de Pós-Graduação em Produtos Naturais e Sintéticos Bioativos, Universidade Federal da Paraíba, João Pessoa, 58051- \\ 970, Brasil.*marcelalinspontes@gmail.com \\ b Programa de Pós-Graduação em Desenvolvimento e Inovação tecnológica em Medicamentos, Universidade Federal da Paraíba, \\ João Pessoa, 58051-970, Brasil
}

Received: 11 dezembro 2017 / Accept: 8 janeiro 2018 / Published online: 20 janeiro 2018

\begin{abstract}
Among natural products, Brazilian propolis stands out for being considered a source for the discovery of new bioactive compounds. In the last decade, a new Brazilian propolis has been described, known as red propolis due to its reddish pigment. Since then, numerous studies revealing its major components and pharmacological activity have been carried out. Thus, this research had the aim of performing an integrative review of literature on the biological activity of Brazilian red propolis. Scientific studies in the PubMed, SciELO and LILACS databases were reviewed and analyzed using an inductive approach and indirect documentation technique. A total of 418 publications were found, and inclusion and exclusion criteria were subsequently applied, selecting a total of 18 articles. Brazilian red propolis presents numerous pharmacological properties, especially antibacterial, antifungal, antioxidant and anti-inflammatory effects. In addition, the chemical composition of this substance is different from other types of propolis already reported in literature, presenting flavonoids never before described. In this way, its chemical characteristics suggest probable therapeutic use for human consumption
\end{abstract}

Keywords: Flavonoids, Apis millifera, bee.

\section{Caracterização química e ação farmacológica da própolis vermelha brasileira}

\section{Resumo}

Dentre os produtos naturais, a própolis brasileira destaca-se por ser considerada uma fonte para a descoberta de novos compostos bioativos. Na última década, foi descrita uma nova própolis brasileira, conhecida como própolis vermelha devido ao seu pigmento avermelhado. Desde então, inúmeras pesquisas revelando seus componentes majoritários e sua atividade farmacológica têm sido descritas. Dessa forma, esta pesquisa teve o objetivo de realizar uma revisão integrativa da literatura sobre a atividade biológica da própolis vermelha brasileira. Estudos científicos nos bancos de dados PubMed, SciELO e LILACS foram revisados e analisados utilizando-se uma abordagem indutiva e técnica de documentação indireta. Foram encontradas 418 publicações, sendo posteriormente aplicados critérios de inclusão e exclusão, selecionando ao todo 18 artigos. A própolis vermelha brasileira apresenta inúmeras propriedades farmacológicas, destacando-se os efeitos antibacteriano, antifúngico, antioxidante e anti-inflamatório. Além disso, a composição química desta substância é diferente dos demais tipos de própolis já relatados na literatura, apresentando flavonóides que ainda não tinham sido descritos. Dessa forma, suas características químicas sugerem provável uso terapêutico para o organismo humano.

Palavras-chave: Flavonoides, Apis mellifera, abelha.

\section{Introduction}

Medicinal plants are important for pharmacological research and drug development, not only when their constituents are directly used as therapeutic agents, but also as raw materials for synthesis or models for pharmacologically active compounds (WHO, 2014). According to the World Health Organization (WHO), in developed countries, $25 \%$ of medicines are derived from plants, and about $80 \%$ of developing countries rely on traditional medicines where $85 \%$ of these are produced from plant extracts (Xavier et al., 2015). These products present small molecules known as secondary metabolites, which are not involved in the vital processes of cells and have as main function of increasing the probability of survival of a living being by repelling or attracting other organisms (Gurnani et al., 2014).

The consumption of drugs of natural origin has been the target of consumers and researchers in recent decades. The search for treatment with low cost, efficacy and minimized side effects has been the motivation of this growth (Van Boeckel et al., 2014).

Almost all ancient civilizations knew and used beederived products as valuable resources in their medicine 
(Wagh, 2013). Among apiculture products, propolis stands out because it has been traditionally used for centuries (Tiveron et al., 2016). It is a resinous substance with characteristic aroma, whose color varies from yellowish, light greenish red to dark brown, depending on its botanical origin. It is collected by bees of the species Apis mellifera L., at different plant sites, such as buds, flowers and resinous exudates (Marcucci, 1995). The resin is transported to the hive, processed and added of substances secreted from its metabolism like wax and salivary enzymes (Búfalo et al., 2009).

Brazil is a major producer and exporter of propolis collected by A.mellifera (Oldoni et al., 2015). In the last decade, a new type of propolis produced in mangrove areas of northeastern Brazil, known as red propolis due to its reddish coloration, has been identified.

Knowing the importance of the discovery of natural products with therapeutic effects, together with the lack of scientific studies involving red propolis, this research had as main aim to evaluate the biological activity of Brazilian red propolis, gathering information about the general characteristics, chemical composition and pharmacological activity of this substance.

\section{Material and Methods}

An integrative literature review was carried out with an inductive approach using the indirect documentation technique. Scientific studies available in primary database index banks PubMed, SciELO and LILACS were reviewed and analyzed. The terms used in the search with the Boolean operator AND were: "Brazilian red propolis" AND "pharmacological activity". The inclusion criteria of surveys were: publication in the last five years (2013-2017); free access (open source) and those relating Brazilian red propolis and pharmacological activity. Exclusion criteria were: duplicate versions of publications in the same database or between different databases and studies that did not mention the type of propolis related to the pharmacological effect.

\section{Chemical characterization}

The term propolis derives from the Greek pro "in front of, at the entrance of", and polis, "community or city" (Castaldo and Capasso, 2002; Salatino et al., 2005). This substance is used by bees as a material to seal cracks and holes, preventing the entry of light and microorganisms, while promoting thermal insulation by reducing humidity. It is also used to line combs in order to allow eggs to be deposited by the queen bee and to embalm small dead animals (beetles and insects) that bees could not take out of the hive, avoiding their putrefaction, which could cause infections and diseases (Marcucci et al., 1995; Burdock et al., 1998; Salatino et al., 2005).

Based on the physicochemical properties (color, texture, chemical composition) and due to the diversity of the Brazilian flora, it was possible to classify propolis produced in Brazil into 12 distinct groups, according to the chemical composition and biological activity (Park et al., 2000). The most widely known is green propolis, originating from Baccharis dracunculifolia and artepilin C was recognized as a characteristic constituent of this type of propolis. Three major types of propolis (brown, yellow and red) were characterized based on their secondary classes of metabolites. The brown type is rich in polyisoprenylated benzophenone (PPB) and originates from floral resin of Clusia rosea; the yellow type contains triterpenoids belonging to oleanane, lupane, ursane and lanostane skeletons and its probable botanical origin is Populus spp.

In 2007, a new type of propolis described in scientific literature stood out. It is the $13^{\text {th }}$ type of Brazilian propolis, the red propolis (Alencar et al., 2007; Silva et al., 2008).

In addition to Brazil, red propolis has also been described in Cuba (Piccinelli et al., 2011), Mexico (Lotti et al., 2010) and Venezuela (Trusheva et al., 2006). Its botanical origin was identified as Dalbergia ecastophyllum (L.) Taub., a legume species known for its intense red pigment due to the presence of cationic $\mathrm{C}^{30}$ isoflavones. (Piccinelli et al., 2011) (Figure 1).

D. ecastophyllum, popularly known as rabo-de-bugio or marmelo - do - mangue, is a scandent or semi-prostrate species found associated with estuaries, mangroves and dunes, assisting in the fixation of sand. It is well adapted to conditions of high salinity and its fruits are able to float (Camargo, 2005). According to Mata et al. (2014), the area of occurrence of $D$. ecastaphyllum is very extensive, extending from southern Florida to southern Brazil, as well as on the western coast of Africa. In Brazil, its phytogeographic domains include the Amazon and the Atlantic Forest, covering the Northern (Roraima, Pará and Amazonas), Northeastern (Maranhão, Ceará, Rio Grande do Norte, Paraíba, Pernambuco, Alagoas and Sergipe), Midwestern (Mato Grosso do Sul), Southeastern (Espírito Santo, São Paulo and Rio de Janeiro) and Southern (Paraná and Santa Catarina) regions of Brazil (Lima, 2012).

A. mellifera bees collect the red exudate from holes made by insect on the surface of D. ecastophyllum trunk to produce propolis (Bueno-Silva et al., 2013a).

Unlike other types of propolis, rich in phenolic acids and esters (Pellati et al., 2011), red propolis has a specific chemical composition and presents new components never before reported in other varieties of propolis, such as vestitol and neovestitol (Piccinelli et al., 2011; Bueno-Silva et al., 2013a) and biochamine $\mathrm{A}$, in addition to liquiritigenin, formononetine and medicarpine (Piccinelli et al., 2011; Righi et al., 2011; Frozza et al., 2013; López et al., 2014).

\section{Pharmacological action}

Bueno-Silva et al. (2013a) believe that the chemical composition of red propolis differentiated from other types of propolis has been responsible for the main pharmacological activities of this substance: antibacterial, antifungal, antioxidant and anti-inflammatory (Table 1).

The mechanism of antibacterial activity of the substance can be mainly attributed to cytoplasmic membrane damage caused by the lower membrane fluidity, inhibition of nucleic acid synthesis caused by inhibition of topoisomerase, inhibition of metabolism caused by inhibition of NADHcytochrome c reductase or inhibition of biofilm formation. These mechanisms are related to the presence of flavonoids in red propolis (Bueno-Silva et al., 2013a; Yixi, 2015). Xie et al. (2015) and Freires et al. (2016) also believe that the mechanism of action of this substance is related to damage to 
the plasma membrane of the microorganism, reducing its fluidity and inhibiting the adequate functioning and energetic supply of the cell as it prevents the exchange of nutrients and metabolites.

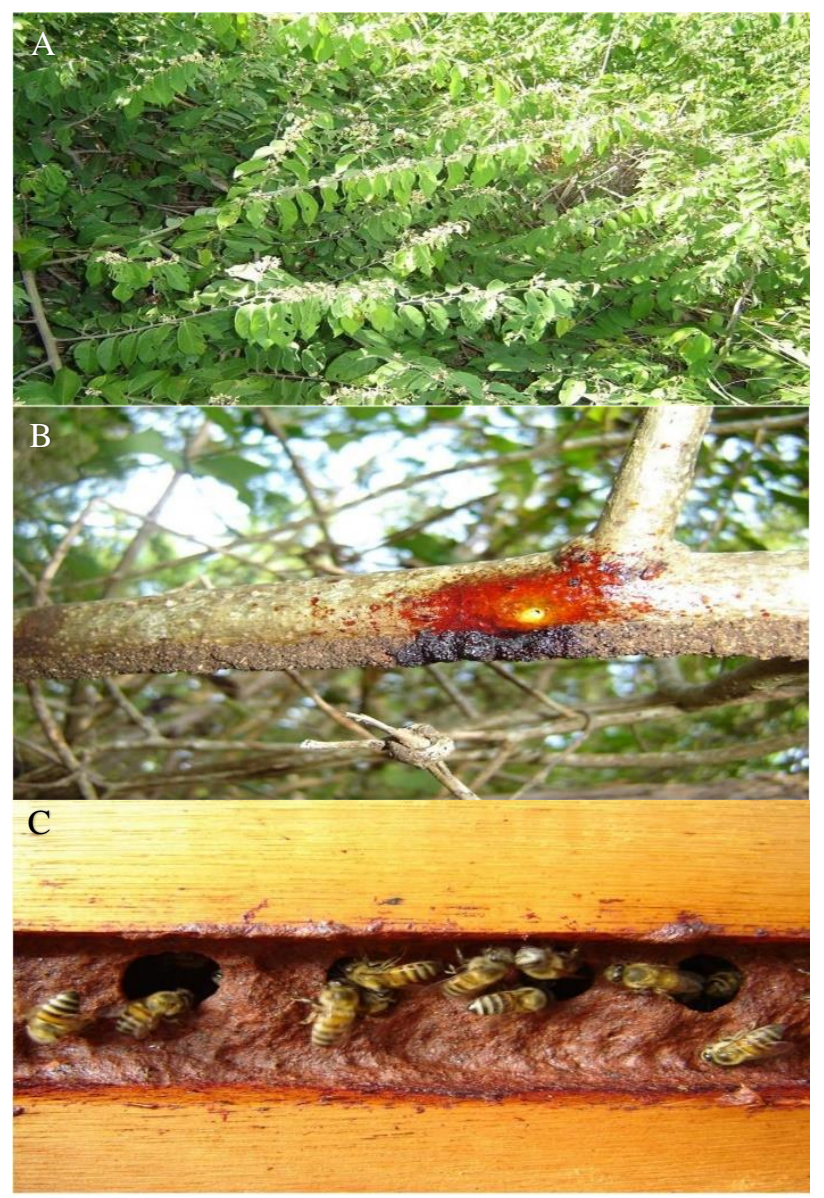

Figure 1. Dalbergia ecastophyllum, the botanical origin of red propolis (A). Reddish exudate at the core of $D$. ecastophyllum (B). Apis mellifera bees using red propolis to seal cracks and holes in the hive $(\mathrm{C})$. Source: Edivaldo Pacheco Filho.

The antioxidant activity of this substance is related to the prevention of formation, neutralization and removal of free radicals associated to the inhibition of the chain of oxidative reactions by red propolis (Oldoni et al., 2011; Frozza et al., 2013). Trusheva et al. (2006) reported that the caffeic extract isolated from red propolis from Alagoas presented antioxidant activity up to $85 \%$ compared to positive control phenylhydrazine. In a study involving organic propolis from southern Brazil, Tiveron et al. (2016) reported high antioxidant activity of their alcoholic extracts. Other authors evaluated the antioxidant effect of the alcoholic extract of red propolis. Oldoni et al. (2011) evaluated the antioxidant activity of red propolis from Maceió (Alagoas) in its hydroalcoholic extract, as well as its isolated chemical compounds, Vestitol, Neovestitol and Isoliquiritigenin. The authors reported higher antioxidant activity of vestitol, followed by the hydroalcoholic extract, neovestitol and isolquiritigenin. In fact, isoflavonoids have already been considered the compounds with the highest antioxidant potential (Lee et al., 2005). Silva et al. (2017) evaluated the antioxidant effect in the hydroalcoholic extract of red propolis from Aracaju (Sergipe) and concluded that this effect is concentration-dependent.

Regarding the antifungal activity, the effect of red propolis appears to be associated with the damage caused to the fungal membrane, affecting the membrane ergosterol and altering its permeability (Pippi et al., 2015, Freires et al., 2016). Neves et al. (2016) studied the crude ethanolic extract of this substance in comparison to its fractionated derivatives in Candida albicans and Candida tropicallis species. The authors concluded that formononetin is an important compound for the antifungal activity demonstrated by red propolis.

As for the anti-inflammatory and immunomodulatory effects, different models of acute and chronic study using red propolis have been studied. Inhibition of prostraglandin, inhibition of prostanoids (especially PGE2) and proinflammatory cytokines (Lustosa et al., 2008), reduction of nitrous oxide pathway, reduction of leukocyte adhesion (Bueno-Silva et al., 2013b) and enzymatic activity during the healing process and inhibition of TNF- $\alpha$ should be considered as different mechanisms used by this substance; however, specific mechanisms of its anti-inflammatory activity have not been yet well understood. In addition, the healing of cutaneous wounds in rodents with the use of red propolis appears to be facilitated by the suppression of the NFKB transcription factor associated with inflammation (Oldoni et al., 2011).

In this context, Bueno-Silva et al. (2016) reported that the ethanolic extract of red propolis subcutaneously administered in mice $(10 \mathrm{mg} / \mathrm{kg})$, was able to reduce the chemotaxis of neutrophils by blocking calcium channels and inflammatory chemical mediators were significantly reduced. Franchin et al. (2016a) reported that Neovestitol, an isoflavonoid isolated from red propolis, reduced acute and chronic inflammation in mice when subcutaneously administered at dose of 3 and 10 $\mathrm{mg} / \mathrm{kg}$. The same authors suggested an anti-inflammatory effect for Vestitol, another isoflavonoid isolated from red propolis at dose of 3 and $10 \mathrm{mg} / \mathrm{kg}$, subcutaneously administered (Franchin et al., 2016b). In addition, a study using formononetin isolated from Brazilian red propolis reported that the administration of this compound in experimental inflammation models in mice reduced leukocyte migration and edema formation (Cavendish et al., 2015).

\section{Factors influencing the red propolis composition}

The constituents of propolis and its pharmacological activity may vary widely from region to region according to local flora, collection season and extraction method (Park et al., 1998; Park et al., 2002; Massaro et al., 2014). Regueira Neto et al. (2017) studied the variation in the concentration of red propolis compounds according to the seasonality.

The authors evaluated that the concentration of chlorogenic acid, caffeic acid and ellagic acid is twice as high in the dry period and the concentration of luteolin and apigenin increases during the rainy season. The authors believe that this is due to the influence of seasonality on the production of secondary metabolites in the D. ecastophyllum resin. 
Table 1. Main chemical components of Brazilian red propolis and its pharmacological effects.

\begin{tabular}{ccccc}
\hline Chemical Component & $\begin{array}{c}\text { Source } \\
\text { (Extract/Fraction) }\end{array}$ & $\begin{array}{c}\text { Geographical } \\
\text { Origin }\end{array}$ & $\begin{array}{c}\text { Biological } \\
\text { Activity }\end{array}$ & Reference \\
\hline Eedicarpine & & & & $\begin{array}{c}\text { Trusheva et al. (2006) } \\
\text { Alencar et al. (2007) } \\
\text { Piccinelli et al. (2011) } \\
\text { Frozza et al. (2013) }\end{array}$ \\
& Antibacterial / \\
antifungal & & Maceió (AL) & & \\
& & &
\end{tabular}

Quercetin<smiles></smiles>

Ethanolic extract / chloroform fraction

Maceió (AL)

Antiinflammatory
Alencar et al. (2007)
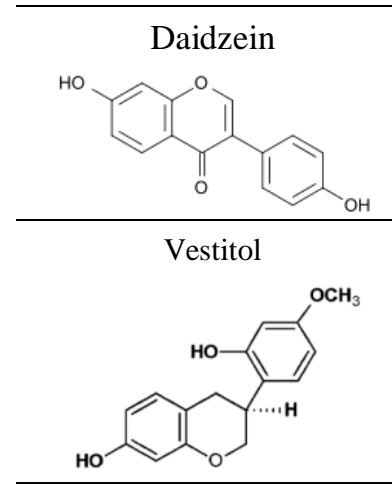

Ethanolic extract / chloroform fraction
Ethanolic extract / chloroform fraction
Maceió (AL) Antioxidant

Alencar et al. (2007)

\begin{tabular}{|c|c|c|c|c|}
\hline Neovestitol & $\begin{array}{l}\text { Ethanolic extract / } \\
\text { Methanolic extract / } \\
\text { Chloroform fraction }\end{array}$ & $\begin{array}{l}\text { Marechal } \\
\text { Deodoro } \\
\quad(\mathrm{AL})\end{array}$ & $\begin{array}{l}\text { Antibacterial, } \\
\text { anticaries, anti- } \\
\text { inflammatory } \\
\text { and antioxidant }\end{array}$ & $\begin{array}{c}\text { Lotti et al. (2010) } \\
\text { Oldoni et al. (2011) } \\
\text { Piccinelli et al. (2011) } \\
\text { Bueno-Silva et al. } \\
\text { (2013) }\end{array}$ \\
\hline
\end{tabular}

Formononetin<smiles>O=c1c(-c2ccc(Cl)cc2)coc2cc(O)ccc12</smiles>

Marechal

Deodoro

(AL)
Antibacterial, anticaries, antiinflammatory and antioxidant
Oldoni et al. (2011)

Piccinelli et al. (2011)

Bueno-Silva et al. (2013)

Lotti et al. (2010)
Ethanolic extract Anticcinelli et al. (2011)
Frozza et al. (2013)

Ferulic acid

Ethanolic extract / Antioxidant Alencar et al. (2007)
chloroform fraction

\section{Liquiritigenin}<smiles>O=C1C[C@H](c2ccc(O)cc2)Oc2cc(O)ccc21</smiles>

Ethanolic extract Maceió (AL) Antiproliferative

Lotti et al. (2010)

Piccinelli et al. (2011)

Frozza et al. (2013)

Mendonça et al. (2015) collected 12 red propolis samples throughout the year in the state of Sergipe. The authors performed extraction with $70 \%$ ethanol and evaluated the variation of color and chemical constituents as a function of climatic variation. It was concluded that there is a gradual variation in color and chemical composition of red propolis, with better yields between the months of April and June. On the other hand, Sforcin et al. (2000), pointed out that propolis collected in Brazil shows no variation in the chemical constitution as a function of time and collection region. 
According to Park et al. (2002), the biological activity of propolis is greater in tropical areas of the planet due to the high plant diversity of these regions.

In addition, propolis extracts can be obtained by different extraction methods. The conventional technique uses ethanol as solvent, while alternative methods, such as extraction of supercritical fluids, have also been described. The extraction method directly affects the yield and selectivity of some components (Machado et al., 2015, Machado et al., 2016). Importantly, propolis obtained by aqueous extraction contains amino acids, organic matter and carbohydrates, which are not present in the ethanol extraction. Aqueous extraction is widely used as additives in food and cosmetics due to its properties and for causing minimal olfactory stimulation. On the other hand, ethanolic extraction provides lipophilic compounds, which are in large amounts and attracts considerable interest from researchers (Machado et al., 2016).

The interest of researchers to know better the usefulness of the different types of propolis has increased, and for this reason, researches in different parts of the world have been carried out and satisfactory results have been found. Its antiseptic, antimycotic, bacteriostatic, astringent, spasmolytic, anti-inflammatory and anesthetic properties have enabled this substance to be used in folk medicine and in the biocosmetic industry, being found commercially in the form of sprays, dentifrices, lotions, tablets, solutions, capsules, creams and chewing gums (Burdock, 1998). However, the medicinal and nutraceutical use of this substance must be certified by an official regulatory agency.

\section{Conclusion}

Due to its distinct chemical composition, red propolis exhibits several biological properties, highlighting its antibacterial, antifungal, antioxidant and anti-inflammatory activity. This substance is promising in the development of health research, adding clinical and commercial benefits. However, considering the variability of existing propolis extracts, it is believed that the standardization on geographical location and forms and solvents used can positively contribute to the quality control, ensuring better biological activity.

\section{References}

Alencar, S.M.; Oldoni, T.L.C.; Castro, M.L.; Cabral, I.S.R.; Costa-Neto, C.M.; Cury, J.A.; Rosalen, P.L.; Ikegaki, M. 2007. Chemical composition and biological activity of a new type of Brazilian propolis: red propolis, J. Ethnopharmacol, 113: 278-283.

Bueno-Silva, B.; Koo, H.; Falsetta, M.L.; Alencar, S.M.; Ikegaki, M.; Rosalen, P.L. 2013a. Effect of Neovestitol-vestitol containing Brazilian red propolis on biofilm accumulation in vitro and dental caries development in vivo. Biofouling, 29(10).

Bueno-Silva, B.; Alencar, S.M.; Koo, H.; Ikegaki, M.; Silva, G.V.; Napimoga, M.H.; Rosalen, P.L. 2013b. Anti-inflammatory and antimicrobial evaluation of neovestitol and vestitol isolated from Brazilian red propolis. Journal of agricultural and food chemistry, 61(19): 4546-4550.

Bueno-Silva, B.; Franchin, M.; Alves, C.F.; Denny, C.; Colón, D.F.; Cunha, T.M.; Alencar, S.M.; Napimoga, M.H.; Rosalen, P.L. 2016. Main pathways of action of Brazilian red propolis on the modulation of neutrophils migration in the inflammatory process. Phytomedicine, 23:1583-1590.

Búfalo, M.C.; Candeias, J.M.G.; Sforcin, J.M. 2009. In vitro effect of Brazilian green propolis on human laryngeal epidermoid carcinoma
(Hep-2) cells. Evid Based Complement Alternat Med, 6(4): 483-7.

Burdock, G.A. 1998. Review of the biological properties and toxicity of bee propolis. Food ChemToxicol, 36: 347-363.

Cabral, I.S.R.; Oldoni, T.L.C.; Prado, A.; Bezerra, R.M.N.; Alencar, S.M.; Kegaki, M.; Rosalen, P. L. 2009. Composição fenólica, atividade antibacteriana e antioxidante da própolis vermelha brasileira. Química Nova, 32(6): 1523-1527.

Camargo, R.A. 2005. A tribo Dalbergieae (Leguminosae -Faboideae) no estado de Santa Catarina, Brasil. Dissertação de Mestrado, Departamento de Botânica da Universidade Federal do Rio Grande do Sul/Rio Grande do Sul, Brasil. 153p.

Castaldo, S; Capasso, F. 2002. Propolis, an old remedy used in modern medicine. Fitoterapia, 1(1).

Cavendish, R.L.; Santos, J.S.; Belo Neto, R.; Paixão, A.O; Oliveira, V.J.; Araujo, E.D.; Silva, A.A.B.; Thomazzi, S.M.; Cardoso, J.C.; Gomes, M.Z. 2015. Antinociceptive and anti-inflammatory effects of Brazilian red propolis extract and formononetin in rodents. J. Ethnopharmacol., 173: $127-133$.

Franchin, M.; Colón, D.F.; da Cunha, M.G.; Castanheira, F.V.; Saraiva, A.L.; Bueno-Silva, B.; Alencar, S.M.; Cunha, T.M.; Rosalen, P.L. 2016 Neovestitol, an isoflavonoid isolated from Brazilian red propolis, reduces acute and chronic inflammation: involvement of nitric oxide and IL-6. Sci Rep., 6(1).

Franchin, M.; Colón, D.F.; Castanheira, F.V; da Cunha, M.G.; Bueno-Silva, B.; Alencar, S.M.; Cunha, T.M.; Rosalen, P.L. 2016b. Vestitol Isolated from Brazilian Red Propolis Inhibits Neutrophils Migration in the Inflammatory Process: Elucidation of the Mechanism of Action. J Nat Prod. 79(4): 954-60.

Freires, I.A.; Alencar, S.M.; Rosalen, P.L. 2016. A pharmacological perspective on the use of Brazilian Red Propolis and its isolated compounds against human diseases. Eur J Med Chem, 110: 267-79.

Frozza, C.D.S., Garcia, C.S.C., Gambato, G., Souza, M.D., Salvador, M., Moura, S., Padilha, F.F., Seixas, F.K., Collares, T., Borsuk, S., Dellagostin, D.A., Henriques, J.A.P., \& Roesch-Ely, M. 2013. Chemical characterization, antioxidant and cytotoxic activities of Brazilian red propolis. Food and Chemical Toxicology, 52: 137-142.

Gurnani, N.; Mehta, D.; Gupta, M.; Mehta, B.K. 2014. Natural Products: source of potential drugs. J. Basic Appl. Sci., 6(6): 171-186.

Kumazawa, S.; Ueda, R.; Hamasaka, T.; Fukumoto, S.; Fujimoto, T.; Nakayama, T. 2007. Antioxidant prenylated flavonoids from propolis collected in Okinawa, Japan. Journal of Agricultural and Food Chemistry, 55: 7722-7725.

Lee, C.H.; Yang, L.; Xu, J.Z.; Yeung, S.Y.V.; Huang, Y.; Chen, Z.Y. 2005 Relative antioxidant activity of soybean isoflavones and their glycosides. Food Chem., 90: 735-741.

Lima, H.C. 2012. Dalbergia em Lista de espécies da flora do Brasil.

López, B.G.; Schmidt, E.M.; Eberlin, M.N.; Sawaya, A.C. 2014. Phytochemical markers of different types of red propolis. Food Chem., 146: $174-80$

Lotti, C.; Campo Fernandez, M.; Piccinelli, A.L.; Cuesta-Rubio, D.; Márquez Hernández, I.; Rastrelli, L. 2010. Chemical constituents of red Mexican propolis. Journal of Agricultural and Food Chemistry, 58(4): 2209-2213.

Lustosa, S.R.; Galindo, A.B.; Nunes, L.C.C.; Randau, K.P.; Rolim Neto, P.J. 2008. Própolis: atualizações sobre a química e a farmacologia. RevBrasFarmacogn, 18: 447-454.

Machado, B.A.S.; Barreto, G.A.; Costa, A.S.; Costa, S.S.; Silva, R.P.D.; Silva, D.F.; Brandao, H.N.; Rocha, J.L.C.; Nunes, S.B.; Umsza-Guez, M.A.; Padilha, F.F. 2015. Determination of parameters for the supercritical extraction of antioxidant compounds from green propolis using carbon dioxide and ethanol as co-solvent. PLoS ONE, 10(8).

Machado, B.A.; Silva, R.P.; Barreto, G.D.E.A.; Costa, S.S.; Silva, D.F.; Brandão, H.N.; Rocha, J.L.; Dellagostin, O.A.; Henriques, J.A.; UmszaGuez, M.A.; Padilha, F.F. 2016. Chemical Composition and Biological Activity of Extracts Obtained by Supercritical Extraction and Ethanolic Extraction of Brown, Green and Red Propolis Derived from Different Geographic Regions in Brazil. PLoS One, 1(1).

Marcucci, M.C. 1995. Propolis: chemical composition, biological properties and therapeutic activity. Apidologie, 26: 83-99.

Mendonça, L.S.; Mendonça, F.M.R.; Araújo, Y.L.F.M. Araújo, E.D.; Ramalho, S.A.; Narain, N.; Jain, S.; Drellana, S.C.; Padilha, F.F.; 
Cardoso, J.C. 2015. Chemical markers and antifungal activity of red propolis from Sergipe, Brazil. Food Sci. Technol, 35(2): 291-298.

Neves, M.V.;Silva, T.M.;Lima, E.O.;Cunha, E.V.;Oliveira, E.J. 2016. Isoflavone formononetin from red propolis acts as a fungicide against Candida sp. Braz J Microbiol., 47(1): 159-66.

Oldoni, T.L.C.; Oliveira, S.C.; Andolfatto, S.; Karling, M.; Calegari, M.A.; Sado, R.Y.; Maia, F.M.C.; Alencar, S.M.; Lima, V.A. 2015. Chemical Characterization and Optimization of the Extraction Process of Bioactive Compounds from Propolis Produced by Selected Bees Apis mellifera. J. Braz. Chem. Soc., 26(10).

Park, Y.K.; Ikegari, M.; Abreu, J.A.S.; Alcici, N.M.F. 1998. Estudo da preparação dos extratos de própolis e suas aplicações. Food Science and Technology, 18(3).

Park, Y.K.; Alencar, S.M.; Scamparine, A.R.P.; Aguiar, C.L. 2002. Própolis produzida no sul do Brasil, Argentina e Uruguai: Evidências fitoquímicas de sua origem vegetal. Ciência Rural, 2: 997-1003.

Pellati, F.; Epifano, F.; Contaldo, N.; Orlandini, G.; Cavicchi, L.; Genovese, S.; Bertelli, D.; Benvenuti, S.; Curini, M.; Bertaccini, A.; Bellardi, M.G.2011. Chromatographic methods for metabolite profiling of virusand phytoplasma-infected plants of Echinacea purpurea. J. Agric. FoodChem, 59: 10425-10434.

Piccinelli, A.L.; Lotti, C.; Campone, L.; Cuesta-Rubio, O.; Campo Fernandez, M.; Rastrelli, L. 2011. Cuban and Brazilian red propolis: botanical origin and comparative analysis by highperformance liquid chromatographyphotodiode array detection/electrospray ionization tandem mass spectrometry. J Agric Food Chem, 59(12): 6484-91.

Pippi, B.; Lana, A.J.; Moraes, R.C.; Güez, C.M.; Machado, M.; de Oliveira, L,F,; Lino von Poser, G.; Fuentefria, A.M. 2015. In vitro evaluation of the acquisition of resistance, antifungal activity and synergism of Brazilian red propolis with antifungal drugs on Candida sp. J Appl Microbiol., 118 (4): 839-50.

Trusheva, B.; Popova, M.; Bankova, V.; Simova, S.; Marcucci, M.C.; Miorin, P.L.; Pasin, F.R.; Tsvetkova, I. 2006. Bioactive constituents of Brazilian red propolis. eCAM, 3:249-254.

Salatino, A.; Teixeira, E.W.; Negri, G.; Message, D. 2005. Origin and Chemical Variation of Brazilian Propolis. Evidence-Based Compl. Altern. Med, 2: 33-8.

Silva, B.B.; Rosalen, P.L.; Cury, J.A.; Ikegaki, M.; Souza, V.C.; Esteves, A. Alencar, S.M. 2008. Chemical composition and botanical origin of red propolis, a new type of Brazilian propolis. Evid Based Complement Alternat Med., 5(3): 313-316.

Sforcin, J.M.; Fernandes, J.r.A.; Lopes, C.A.M.; Bankova, V.; Funari, S.R.C. 2000. Seasonal effect on Brazilian própolis antibacterial activity. J Ethnopharmacol, 73: 243-249.

Regueira Neto, M.S.; Tintino, S.R.; Silva, A.R.P.; Costa, M.S.; Boligon, A.A.; Matias, E.F.F.; Balbinoa, V.Q.; Menezes, I.R.A.; Coutinho, H.D.M. 2017. Seasonal variation of Brazilian red propolis: Antibacterial activity, synergistic effect and phytochemical screening. Food and Chemical Toxicology, 107: 572-580.

Righi, A.A.; Alves, T.R.; Negri, G.; Marques, L.M.; Breyer, H.; Salatino, A. 2011. Brazilian red propolis: unreported substances, antioxidant and antimicrobial activities. J Sci Food Agric., 91(13): 2363-70.

Siqueira, A.B.; Gomes, B.S.; Cambuim, I.; Maia, R.; Abreu, S.; Souza-Motta, C.M.; Queiroz, L.A.; Porto, A.L. 2009. Trichophyton species susceptibility to green and red propolis from Brazil. Lett Appl Microbiol., $48(1)$.

Tiveron, A.P.; Rosalen, P.L.; Ranchin, M.; Lacerda, R.C.C.; Bueno-Silva, B.; Benso, B.; Denny, C.; Ikegari, M.; Alencar, S.M. 2016. Chemical Characterization and Antioxidant, Antimicrobial, and Anti-Inflammatory Activities of South Brazilian Organic Propolis. PLoS One, 11(11).
Van Boeckel, T.P.; Gandra, S.; Ashok, A.; Caudron, Q.; Levin, S.A. 2014. Laxminarayan R. Global antibiotic consumption 2000 to 2010: an analysis of national pharmaceutical sales data. Lancet Infect Dis, 14: 74250.

Wagh, V.D. 2013. Propolis: a wonder bees product and its pharmacological potentials. Adv Pharm Sci, (1).

World Health Organization. 2014. Antimicrobial Resistance: Global Report on Surveillance. World Health Organization, Geneva, Switzerland. 257p.

Xavier, T.F.; Kannan, M.; Auxilia, A. 2015. Observation on the traditional phytotherapy among the Malayali tribes in Eastern Ghats of Tamil Nadu, South India. J. Ethnopharmacol., 165(1).

Xie, X.L.; Gi, M.; Fujioka, M.; Doi, K.; Yamano, S.; Tachibana, H.et al. 2015. Ethanol-extracted propolis enhances BBN-initiated urinary bladder carcinogenesis via non-mutagenic mechanisms in rats. Food ChemToxicol, 83: 193-200.

Yixi, X.; Yang, W.; Tang, F.; Chen, X.; Ren, L. 2015. Antibacterial Activities of Flavonoids: Structure-Activity Relationship and Mechanism. Current Medicinal Chemistry, 22: 132-149. 